OPEN ACCESS

Edited by:

Aldo R. Boccaccini, University of Erlangen-Nuremberg,

Germany

Reviewed by:

Steve Meikle,

University of Brighton, UK

Alexander Hoppea,

Johnson Matthey, Netherlands

${ }^{*}$ Correspondence:

Akiko Obata

obata.akiko@nitech.ac.jp;

Toshihiro Kasuga kasuga.toshihiro@nitech.ac.jp

Specialty section:

This article was submitted to Biomaterials,

a section of the journal Frontiers in Bioengineering and Biotechnology

Received: 30 June 2015 Accepted: 17 November 2015 Published: 02 December 2015

Citation:

Yamada S, Obata A, Maeda H, Ota Y and Kasuga T (2015) Development of Magnesium and Siloxane-Containing Vaterite and Its Composite Materials for Bone Regeneration.

Front. Bioeng. Biotechnol. 3:195. doi: 10.3389/fbioe.2015.00195

\section{Development of Magnesium and Siloxane-Containing Vaterite and Its Composite Materials for Bone Regeneration}

\author{
Shinya Yamada ${ }^{1}$, Akiko Obata ${ }^{1 *}$, Hirotaka Maeda ${ }^{1}$, Yoshio Ota $^{2}$ and Toshihiro Kasuga ${ }^{1 *}$ \\ ${ }^{1}$ Department of Frontier Materials, Graduate School of Engineering, Nagoya Institute of Technology, Nagoya, Japan, \\ ${ }^{2}$ Yabashi Industries Co., Ltd., Ogaki, Japan
}

Development of novel biomaterials with $\mathrm{Mg}^{2+}, \mathrm{Ca}^{2+}$, and silicate ions releasability for bone regeneration is now in progress. Several inorganic ions have been reported to stimulate bone-forming cells. We featured $\mathrm{Ca}^{2+}$, silicate, and especially, $\mathrm{Mg}^{2+}$ ions as growth factors for osteoblasts. Various biomaterials, such as ceramic powders and organic-inorganic composites, that release the ions, have been developed and investigated for their cytocompatibilities in our previous work. Through the investigation, providing the three ions was found to be effective to activate osteogenic cells. Magnesium and siloxanecontaining vaterite was prepared by a carbonation process as an inorganic particle that can has the ability to simultaneously release $\mathrm{Ca}^{2+}$, silicate, and $\mathrm{Mg}^{2+}$ ions to biodegradable polymers. Poly (L-lactic acid) (PLLA)- and bioactive PLLA-based composites containing vaterite coatings were discussed regarding their degradability and cytocompatibility using a metallic Mg substrate as $\mathrm{Mg}^{2+}$ ion source. PLLA/SiV composite film, which has a releasability of silicate ions besides $\mathrm{Ca}^{2+}$ ion, was coated on a pure $\mathrm{Mg}$ substrate to be compared with the PLLAN coating. The degradability and releasability of inorganic ions were morphologically and quantitatively monitored in a cell culture medium. The bonding strength between the coatings and Mg substrates was one of the key factors to control $\mathrm{Mg}^{2+}$ ion release from the substrates. The cell culture tests were conducted using mouse osteoblast-like cells (MC3T3-E1 cells); cellular morphology, proliferation, and differentiation on the materials were evaluated. The PLLAN and PLLA/SiV coatings on Mg substrates were found to enhance the proliferation, especially the PLLA/SiV coating possessed a higher ability to induce the osteogenic differentiation of the cells.

Keywords: bioceramics, magnesium, calcium, silicate, bone regeneration

\section{INTRODUCTION}

Various types of bioactive ceramics and glasses have been investigated for application in bone regeneration (Jarcho, 1981; Winter et al., 1981; LeGeros, 2002). Calcium phosphate and calcium silicate glasses, such as Bioglass ${ }^{\circledR} 45 \mathrm{~S} 5$, are well known to have excellent bioactivity and promote new bone formation in vivo. Recently, several ions released from these materials have been found to influence cell functions and some of the ions can accelerate osteogenesis, angiogenesis, and 
antibacterial activity (Hoppe et al., 2011). Calcium $\left(\mathrm{Ca}^{2+}\right)$ ions released from composite materials, consisting of a type II collagen gel and hydroxyapatite (HA), have been demonstrated to have a stimulatory effect on the activation of mouse primary osteoblasts (Maeno et al., 2005). $\mathrm{Ca}^{2+}$ ion concentrations of 2-4 mM are reported to be suitable for enhancing the proliferation and survival of osteoblasts, whereas concentrations of 6-8 $\mathrm{mM}$ favor their differentiation and biomineralization of extracellular matrix (ECM). $\mathrm{Ca}^{2+}$ ion concentrations $>10 \mathrm{mM}$ were found to be cytotoxic for cells.

Stimulatory effects for the enhancement of bone formation were found for the soluble silica species and $\mathrm{Ca}^{2+}$ ions that were released from Bioglass ${ }^{\circledR}$ 45S5 (Xynos et al., 2000a). The cellular numbers of human osteoblasts (HOBs) cultured in the ionic products of Bioglass ${ }^{\circledR} 45 \mathrm{~S} 5$, obtained by its dissolution in Dulbecco's modified eagle medium (DMEM), increased by $155.1 \pm 6.5 \%$ compared with normal DMEM after 4 days of culture. HOBs cultured on the Bioglass ${ }^{\circledR}$ 45S5 disk exhibited higher alkaline phosphatase (ALP) activity, which is known to be associated with osteoblastic differentiation of HOBs, compared with those grown on a bioinert (plastic) substrate, after 6 days of culture (Xynos et al., 2000b). Trace amounts of $\mathrm{Ca}^{2+}$ and silicate ions are believed to be beneficial for the promotion of bone formation.

Additionally, magnesium $\left(\mathrm{Mg}^{2+}\right)$ ions have been reported to enhance cell adhesion to materials, along with the differentiation and biomineralization of osteoblasts. The expression of various integrin family members, which are a class of adhesion proteins, was increased on $\mathrm{Mg}^{2+}$-modified alumina compared with $\mathrm{Mg}^{2+}$ free controls (Zreiqat et al., 2002). The stimulatory effects of $\mathrm{Mg}^{2+}$ ions on early bone cell differentiation have also been reported, whereby osteoblasts cultured on bioactive $\mathrm{SiO}_{2}-\mathrm{CaO}-\mathrm{P}_{2} \mathrm{O}_{5}-$ MgO glass exhibited a high ALP activity (Saboori et al., 2009). Moreover, the effects of $\mathrm{Mg}^{2+}$ ions on angiogenic function have been clarified by Maier et al. (2004). $\mathrm{Mg}^{2+}$ ions stimulate the proliferation of human umbilical vein endothelial cells (HUVECs) and enhance the mitogenic response to angiogenic factors. These stimulatory effects of the released inorganic ions on cellular activities should be beneficial to the design of new biomaterials for bone regeneration.

Magnesium- and siloxane-containing vaterite $(\mathrm{MgSiV})$ has been developed as a material that provides $\mathrm{Mg}^{2+}, \mathrm{Ca}^{2+}$, and silicate ions upon degradation in our previous work (Yamada et al., 2014a). Of the calcium carbonates, vaterite, calcite, and aragonite, vaterite is the most thermodynamically unstable polymorph. The chemical structure and their degradation behavior in physical condition were examined. From cell culture tests, mouse osteoblast-like cells had an improved proliferation, differentiation, and mineralization in the extract of the $\mathrm{MgSiV}$ and the dependence on the ion-type contained in the extract; these cell functions were significantly enhanced when all of the ions, $\mathrm{Mg}^{2+}, \mathrm{Ca}^{2+}$, and silicate ions, were simultaneously provided to the cells.

The improved functions of the cells were also observed in the results of the cell culture tests for metallic magnesium $(\mathrm{Mg})$ substrates coated with a siloxane-containing vaterite $(\mathrm{SiV})$ and poly (L-lactic acid) (PLLA) composite layer (Yamada et al., 2013, 2014b). The metallic Mg substrate coated with the composite layer releases the three kinds of ions at the same time; $\mathrm{Ca}^{2+}$ and silicate ions are supplied by $\mathrm{SiV}$, and $\mathrm{Mg}^{2+}$ ions are from the metallic $\mathrm{Mg}$ substrates. The cell proliferation and differentiation were accelerated on the metallic $\mathrm{Mg}$ substrate coated with the composite layer in comparison with those on the sample releasing only $\mathrm{Ca}^{2+}$ and $\mathrm{Mg}^{2+}$ ions or no ions.

The up-regulation effects by the three kinds of ions on the cells were found to be similar even though the providing process was different between the $\mathrm{MgSiV}$ and the Mg substrate coated with the composite layer. These findings imply that biomaterials providing the three kinds of ions would be good for achievement of the rapid mineralization of osteogenic cells. In addition, such inorganic ions supplied by bioceramics can be regarded to be one of the important factors for promoting bone formation in vivo.

In this review, we provide an overview of materials providing $\mathrm{Mg}^{2+}, \mathrm{Ca}^{2+}$, and silicate ions, i.e., the $\mathrm{MgSiV}$ and the $\mathrm{Mg}$ substrates coated with PLLA/SiV composite layer, and osteoblastlike cell reactions to the materials. In addition, new composite materials that possess an excellent 3D structure (cotton wool-like structure), flexibility, and a providing ability of $\mathrm{Ca}^{2+}$ and silicate ions are introduced as well. They have been expected to be good candidates for bone fillers.

\section{MAGNESIUM- AND SILOXANE-CONTAINING VATERITE}

The development of SiV (Nakamura et al., 2013) and its composites with biodegradable polymer, such as PLLA or poly(lactic-coglycolic acid) (PLGA), as materials providing $\mathrm{Ca}^{2+}$ and silicate ions has been published in our previous work (Obata et al., 2009, 2010; Wakita et al., 2010; Fujikura et al., 2013). Electrospun fibremats consisting of the PLLA/SiV composites possessed excellent cell compatibility in vitro and a formation of mineralized tissue in vivo. Especially, in the results of cell culture tests, the PLLA/SiV composites accelerated the proliferation and the differentiation of mouse osteoblast-like cells in comparison with a composite consisting of vaterite and PLLA (Obata et al., 2009). This implies that the ions released from the PLLA/SiV composites, particularly silicate ions, must contribute to the enhanced cell functions. Many reports demonstrated that such ions are able to enhance osteogenic cell functions, proliferation, differentiation, and mineralization, and regarded to be one of the important factors for bone formation in the body (Hoppe et al., 2011). Thus, the $\mathrm{SiV}$-containing composites are expected to be some of the good candidates for new biomaterials promoting bone formation.

In contrast, the ions released from the $\mathrm{SiV}$ and its composites are believed to have no up-regulation effect on cell adhesion. Cell adhesion is a significant process of progressing proliferation for adherent cells, such as osteoblasts and fibroblasts. To improve cell adhesion should be useful to improve proliferation and following biological reactions of these cells. $\mathrm{Mg}^{2+}$ ions have been found to improve cell adhesion to substrate surfaces (Zreiqat et al., 2002). Thus, to incorporate magnesium to the $\mathrm{SiV}$ was expected to achieve new biomaterials having higher cell compatibility, along with enhanced cell adhesion, proliferation, differentiation, and mineralization. In addition, $\mathrm{MgSiV}$ is expected to possess buffering action in aqueous solution since it releases carbonate ions as well, while most of silica-based bioactive glasses, such 
as 45S5-type bioactive glass, increase its surrounding $\mathrm{pH}$. This might be good for cells cultured on the material surfaces. The preparation of $\mathrm{MgSiV}$ powders has been reported in our previous work (Yamada et al., 2014a). In the present short review, some of their significant results are introduced briefly.

\section{Preparation}

Magnesium and siloxane-containing vaterite powders were synthesized by a carbonation process in methanol using calcium hydroxide, 3-aminopropyltriethoxysilane (APTES), and magnesium hydroxide as calcium, silicate, and magnesium sources, respectively (Yamada et al., 2014a). All the chemicals were mixed into the slurry under carbon dioxide gas flow, resulting in the formation of a precursor gel. The obtained gel was aged for $12 \mathrm{~h}$ at room temperature, dried at $110^{\circ} \mathrm{C}$ for $24 \mathrm{~h}$, and then grounded to form particles. The obtained $\mathrm{MgSiV}$ contained $2.0 \mathrm{wt} \%$ of magnesium and $2.8 \mathrm{wt} \%$ of silicon. $\mathrm{SiV}$ powders were also prepared by the same method without adding magnesium source.

\section{Structure}

The prepared $\mathrm{MgSiV}$ samples exhibit flat-spherical morphology, around $1.3 \mu \mathrm{m}$ in diameter and $0.6 \mu \mathrm{m}$ in thickness (Figure 1). They consist of primary particles with several being $10 \mathrm{~nm}$ in size. On the other hand, the $\mathrm{SiV}$ have a spherical morphology, $\sim 1.4 \mu \mathrm{m}$ in diameter. The reason why the morphologies are different between the two samples is that it is expected that the orientation of the vaterite phase in $\mathrm{MgSiV}$ might be varied by $\mathrm{Mg}^{2+}$ ions. Vaterite is known to have a characteristic symmetry and orientation of carbonate ions in its crystalline structure. The orientation is parallel to the $c$-axis (Wang and Becker, 2009). The siloxane derived from APTES is believed to contribute to the stabilization of the $c$-face (Nakamura et al., 2013). The $\mathrm{Mg}^{2+}$ ions in the $\mathrm{MgSiV}$ might influence the orientation, resulting in the formation of the flat-spherical particles. The surface areas of the two samples are also different; they were 103 and $34 \mathrm{~m}^{2} / \mathrm{g}$ for the $\mathrm{MgSiV}$ and $\mathrm{SiV}$, respectively, from the results of BET-nitrogen adsorption.

The crystalline phase of $\mathrm{MgSiV}$ consists predominantly of vaterite one and contains small amounts of calcite and calcium magnesium carbonate. X-ray diffraction (XRD) pattern of the $\mathrm{MgSiV}$ demonstrates that the peaks corresponding to the $c$-axisdependent plane of vaterite shifted to a higher angle (Figure 2). By

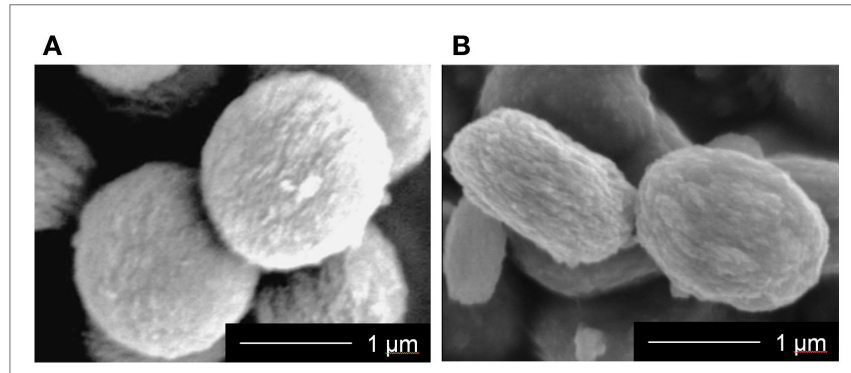

FIGURE 1 | SEM images of (A) SiV and (B) MgSiV. Reprinted with permission from Yamada et al. (2014a). contrast, the $a b$ plane shows no shift. Mg might be incorporated into the vaterite crystalline structure and substitute for some of the Ca-sites in vaterite, since the lattice spacing for the vaterite (004) plane changed from 0.426 to $0.421 \mathrm{~nm}$ by adding $\mathrm{Mg}$ to $\mathrm{SiV}$. The $\mathrm{MgSiV}$ and $\mathrm{SiV}$ were found to also contain the amorphous calcium carbonate (ACC) phase in their structures from the results of Fourier transform infrared spectroscopy (FTIR) analysis (data not shown here).

\section{Ion Release}

The $\mathrm{MgSiV}$ powders release $\mathrm{Mg}^{2+}, \mathrm{Ca}^{2+}$, and silicate ions through their crystalline transformation from vaterite to aragonite phase in aqueous solution. They were immersed in the Tris- $\mathrm{HCl}$ buffer solution ( $\mathrm{pH} 7.4$ ) for 7 days, and the amount of the released ions was measured by inductively coupled plasma atomic emission spectroscopy (ICP-AES) (Figure 3). Their crystalline phases at each time point during the immersion were characterized by XRD (Figure 4). The crystalline phase of the MgSiV transformed from vaterite into aragonite in $12 \mathrm{~h}$ after the immersion and simultaneously released $60 \%$ of the total $\mathrm{Mg}$ and $80 \%$ of the total Si. The release of the two ions continued until day 7 , while the release rate decreased after $12 \mathrm{~h}$. A total amount of $83 \%$ of the total $\mathrm{Mg}$ and almost all $\mathrm{Si}$ in the $\mathrm{MgSiV}$ were released in the 7 days. On the other hand, the Ca-release behavior was different from those of $\mathrm{Mg}$ and $\mathrm{Si}$. The amount of the released $\mathrm{Ca}$ was maximum after $12 \mathrm{~h}$ and then continued to decline until day 7 . The increase in the $\mathrm{Ca}$ amount in $12 \mathrm{~h}$ after the immersion is believed to originate from the dissolution of ACC. On the other hand, the decline in the amount is due to the formation of precipitates at the bottom of the containers used.

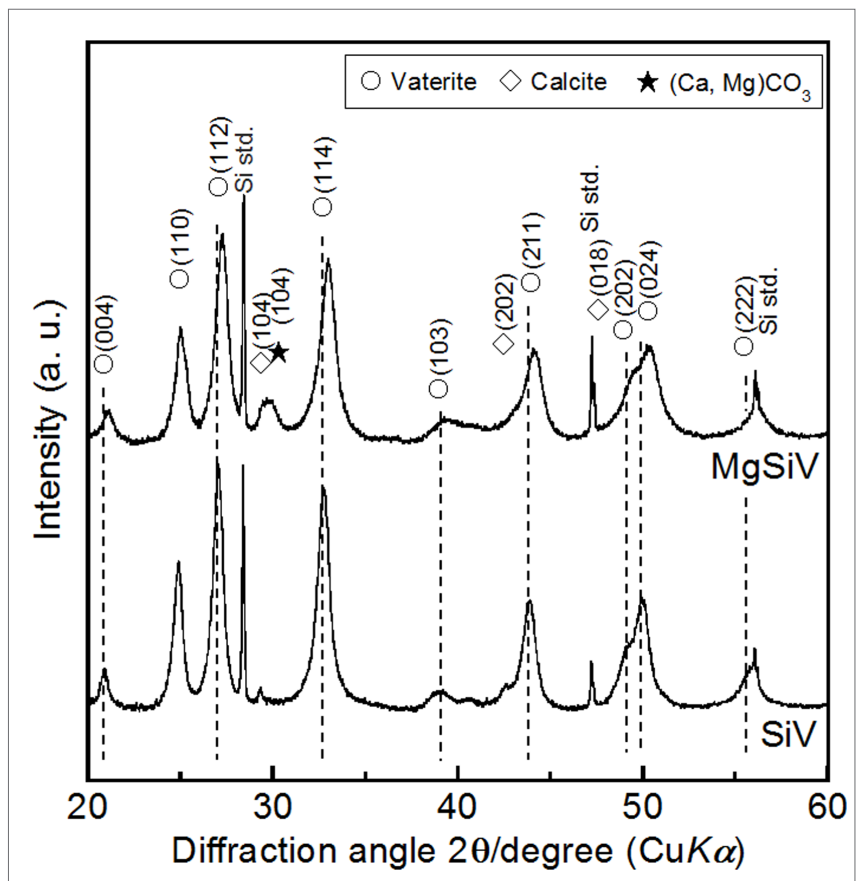

FIGURE 2 | XRD patterns of SiV and MgSiV. Reprinted with permission from Yamada et al. (2014a). 

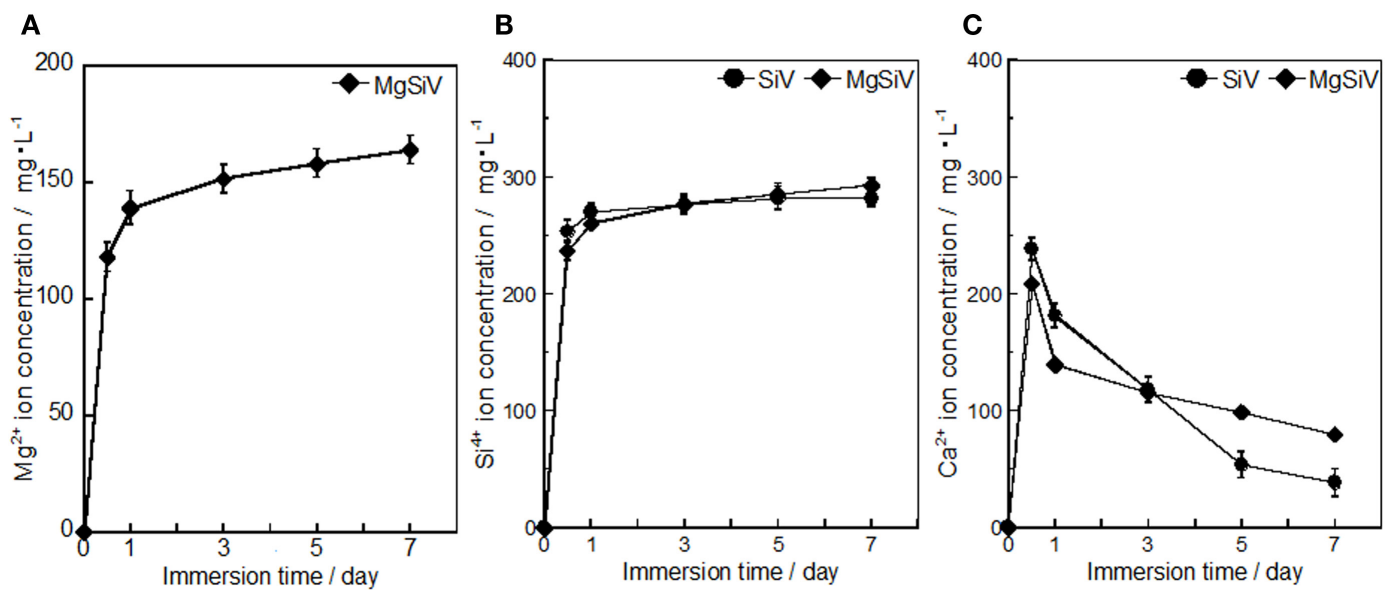

FIGURE 3 | Amounts of (A) Mg, (B) Si, and (C) Ca elements dissolved from SiV and MgSiV. Reprinted with permission from Yamada et al. (2014a).

The $\mathrm{SiV}$ powders possess ion-release behavior similar to the MgSiV. The transformation of the crystal phase of the SiV is, however, different from the $\mathrm{MgSiV}$; its phase changed from vaterite to calcite in $12 \mathrm{~h}$ after the immersion. This is because aragonite phase precipitates more easily in an aqueous solution containing a large amount of $\mathrm{Mg}^{2+}$ ions (Kitano, 1962; Bischoff, 1968; Sawada et al., 1990; Böttcher et al., 1997; Morse et al., 1997; Kitamura, 2001; Zhang et al., 2012). No $\mathrm{Mg}^{2+}$ ion is incorporated in the lattice of aragonite because it has a tightly bound hydration shell (Falini et al., 1996, 2009). After 12 h, small peaks corresponding to vaterite phase are still seen for the $\mathrm{MgSiV}$, while the crystal phase of $\mathrm{SiV}$ completely transformed to calcite. $\mathrm{Mg}$ must be incorporated into the vaterite crystalline structure in the $\mathrm{MgSiV}$, since the peaks corresponding to vaterite in the $\mathrm{MgSiV}$ shifted compared with those of the SiV. The Mg incorporated into the vaterite dissolved from the MgSiV in $12 \mathrm{~h}$, because the peaks revert to the original positions of the SiV. Vaterite disappeared and the predominant crystalline phase was aragonite after 7 days. The particle shape of the $\mathrm{MgSiV}$ varied after the immersion; no original $\mathrm{MgSiV}$ particles were found, but needle-like ones, which is a typical shape of aragonite, were newly observed in the samples after 7 days of immersion.

\section{PLLA/SIV COMPOSITE COATING ON A METALLIC MAGNESIUM SUBSTRATE}

Metallic Mg and its alloys possess biodegradability and proper mechanical properties and are regarded to be good candidates for metallic biomaterials (Staiger et al., 2006; Witte et al., 2008; Witte, 2010). They have the suitable properties for being used as vascular stents or orthopedic implants; they possess high reactivity with water and dissolve in body fluid through corrosion, which would contribute to the avoidance of secondary surgery after healing and achieve a complete replacement of bone tissue. In addition, they have the similar Yong's modulus (41-45 GPa) to that of human cortical bone, which might contribute to the decrease of bone resorption around the implants. The modulus is lower than that of any other metallic biomaterials, such as titanium alloys (Staiger et al., 2006).

On the other hand, there are concerns that metallic $\mathrm{Mg}$ rapidly degrades and produces corrosion, hydroxyl ions, and bubbles of hydrogen gas around the surrounding tissues (Witte et al., 2005). This induces an extremely high local alkali concentration ( $\mathrm{pH}>9.0)$ on the metallic Mg surface, which is harmful for cells (Shen et al., 2012). The bubbles of hydrogen gas formed in 1 week after implantation, which induced vacant spaces around the metallic Mg. This is attributed to poor integration of the metallic Mg implanted into body tissue (Witte et al., 2005). To solve these problems, the metallic $\mathrm{Mg}$ surfaces were coated with biodegradable polymer, such as poly( $\varepsilon$-caprolactone) (PCL) and PLLA (Wong et al., 2010; Xu and Yamamoto, 2012). The cytocompatibility of the metallic $\mathrm{Mg}$ was improved by the polymer coatings.

Bioactive coatings consisting of PLLA-based composites containing $\mathrm{SiV}$ or vaterite $(\mathrm{V})$ powders have been developed in our previous work, since $\mathrm{Mg}^{2+}, \mathrm{Ca}^{2+}$, and silicate ions must be provided from the metallic $\mathrm{Mg}$, vaterite phase, and siloxane in the $\mathrm{SiV}$, respectively, which were expected to enhance osteogenic cell activities. The adhesion, proliferation, and differentiation of MC3T3-E1 cells cultured on the prepared samples were estimated to clarify the effects of the each ion released from the samples on the cell functions (Yamada et al., 2013, 2014b).

\section{Preparation}

The SiV and V powders were prepared by a carbonation method aforementioned. The composites of PLLA and SiV or V were prepared by a melt-blending method, dissolved in chloroform, and then coated on surfaces of a commercially available pure metallic $\mathrm{Mg}$ with a spin coater. The amount of $\mathrm{SiV}$ or $\mathrm{V}$ in the composites was set to be $60 \mathrm{wt} \%$ ( 47 vol\%).

\section{Morphology, Bonding Strength, and Degradation}

The surface morphology of the coatings on the metallic $\mathrm{Mg}$ was different among the PLLA/SiV, PLLA/V, and pure PLLA 


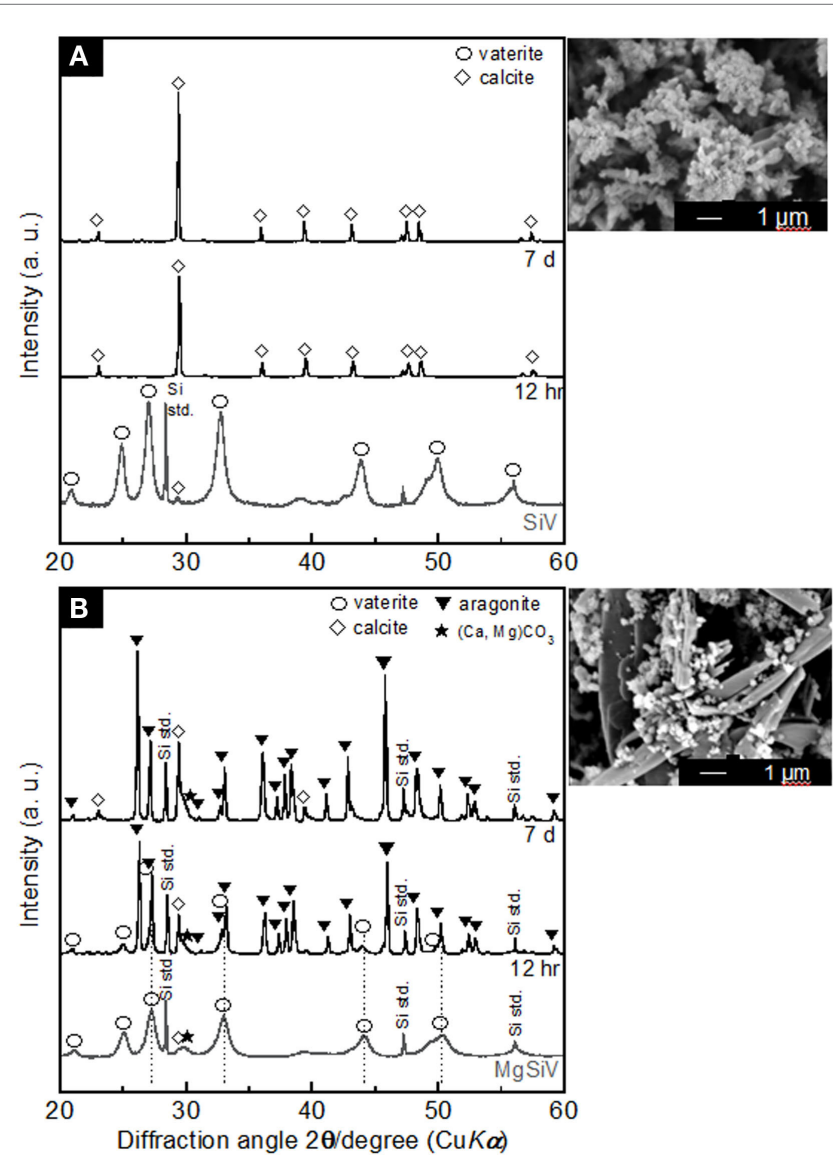

FIGURE 4 | XRD patterns of (A) SiV and (B) MgSiV before and after soaking in Tris buffer solution (pH 7.4) and their SEM images after $\mathbf{7}$ days of the soaking. Reprinted with permission from Yamada et al. (2014a).

(Figures 5A-C), since the diameters of the powders are different; it is $\sim 1.5 \mu \mathrm{m}$ for $\mathrm{SiV}$ and $0.5 \mu \mathrm{m}$ for $\mathrm{V}$. The thickness also varied among them; it was $5.3 \pm 0.4,3.0 \pm 0.1$, and $1.8 \pm 0.2 \mu \mathrm{m}$ for PLLA/SiV, PLLA/V, and pure PLLA. Roughnesses of the coatings were $0.40 \pm 0.00,0.19 \pm 0.01$, and $0.08 \pm 0.01 \mu \mathrm{m}$ for the PLLA/SiV, PLLA/V, and pure PLLA, respectively. This might be due to the difference in the viscosity of the composite or pure PLLA solution. The layer prepared using a spin-coating method depends on the concentration and viscosity of polymer solutions (Schubert and Dunkel, 2003).

Tensile bonding strength tests for the three types of coating demonstrated that the PLLA/SiV coating possesses the highest strength; the rank order of the strength was the PLLA/ $\mathrm{SiV}>\mathrm{PLLA} / \mathrm{V}>$ pure PLLA. The difference in the bonding strength would be due to the changes in the molecular weight of PLLA in the coatings by adding the powders. The bonding mechanism was reported to be influenced by molecular weight of polymer in coatings (Xu and Yamamoto, 2012). More free ends of the polymer chains are in the polymers with a lower molecular weight in comparison with those with a higher molecular weight. In the case of the PLLA composite coatings, a larger number of free carboxyl groups for electrostatic intermolecular interaction between polymer chain and the metallic Mg surface is supposed to be contained in PLLA/SiV, based on the results of the tensile bonding tests. The molecular weights are, however, $82 \mathrm{kDa}$ for PLLA/SiV, $46 \mathrm{kDa}$ for PLLA/V, and $90 \mathrm{kDa}$ for pure PLLA. The varied coating thicknesses of the coatings between them might contribute to the differences in the bonding strength.

All the coated samples release a trace amount of $\mathrm{Mg}^{2+}$ ions in $\alpha$-MEM, while no detachment of the coating layer from the metallic Mg substrates was happened for them. The amount of the ions significantly decreases by the coatings compared with the uncoated (pure) metallic Mg, except the PLLA/V coating (Figure 6). Up to $30 \mu \mathrm{g} / \mathrm{mL}$ of the ions were released from the uncoated Mg for 7 days of culturing. On the other hand, the PLLA/ $\mathrm{SiV}$ and PLLA-coated samples released only 11 and $5 \mu \mathrm{g} / \mathrm{mL}$ of the ions, respectively. The PLLA/V-coated sample possessed a completely different releasing behavior from those of the other two samples; the value of the released ions was the same level of the uncoated $\mathrm{Mg}$ at day $3(16 \mu \mathrm{g} / \mathrm{mL})$ and then reached about 1.4 times as large as that at day $7(43 \mu \mathrm{g} / \mathrm{mL})$. This might be because a large amount of pores formed on the surface of the PLLA/V coating, while no pore or tiny one were done on the surfaces of the other two samples (Figures 5D-F). The pores on the PLLA/V coating were generated through the detachment of $\mathrm{V}$ powders and the degradation of the PLLA matrix. The $\mathrm{Ca}^{2+}$ ions released from the PLLA/V coating might accelerate the corrosion of the metallic $\mathrm{Mg}$, resulting in the enhanced release of $\mathrm{Mg}^{2+}$ ion. Thus, the chemical component of the filler in coatings is important for achievement of suppressing the corrosion of the metallic $\mathrm{Mg}$ and the rapid release of $\mathrm{Mg}^{2+}$ ions from the substrates.

\section{Cytocompatibility}

The proliferation of MC3T3-E1 cells on the three types of coated samples and the uncoated one was evaluated by counting live cells after 1, 3, and 7 days of culturing (Figure 7A). Results represent the mean values of the experiments in triplicate. Statistical analysis was performed using Student's $t$-test and single-factor ANOVA (SPSS 21 software; IBM, USA) followed by Tukey's multiple comparison test. Values of $p<0.05$ were considered to be significant. Although almost no proliferation ability was found for the cells cultured on the metallic $\mathrm{Mg}$, the cells proliferated on the coated samples, especially the proliferation on the PLLA/SiV- and PLLA/V-coated samples was excellent. The uncoated sample should degrade rapidly and generate extremely high alkali condition surrounding its surface after seeding the cells, resulting in the poor cell activity. The polymer coatings suppress such harmful influence on the seeded cells by the metallic Mg, which improves the cell activity. The surface morphology and roughness of the coatings might relate to the cell proliferation ability. However, although the PLLA/SiV coating possess much rougher surface than the PLLA/V one, the proliferation ability of the cells was the similar between the two samples. The crystallinity of polymer was also reported to influence cell proliferation (Park and Cima, 1996; Iafisco et al., 2012). The crystallinities of PLLAs in the PLLA/SiV, PLLA/V, and pure PLLA coatings were 12,9 , and $14 \%$, respectively. Thus, the cells on the samples can be regarded to proliferate independently of the crystallinity of the coatings. The $\mathrm{Ca}^{2+}$ and $\mathrm{Mg}^{2+}$ ions released 

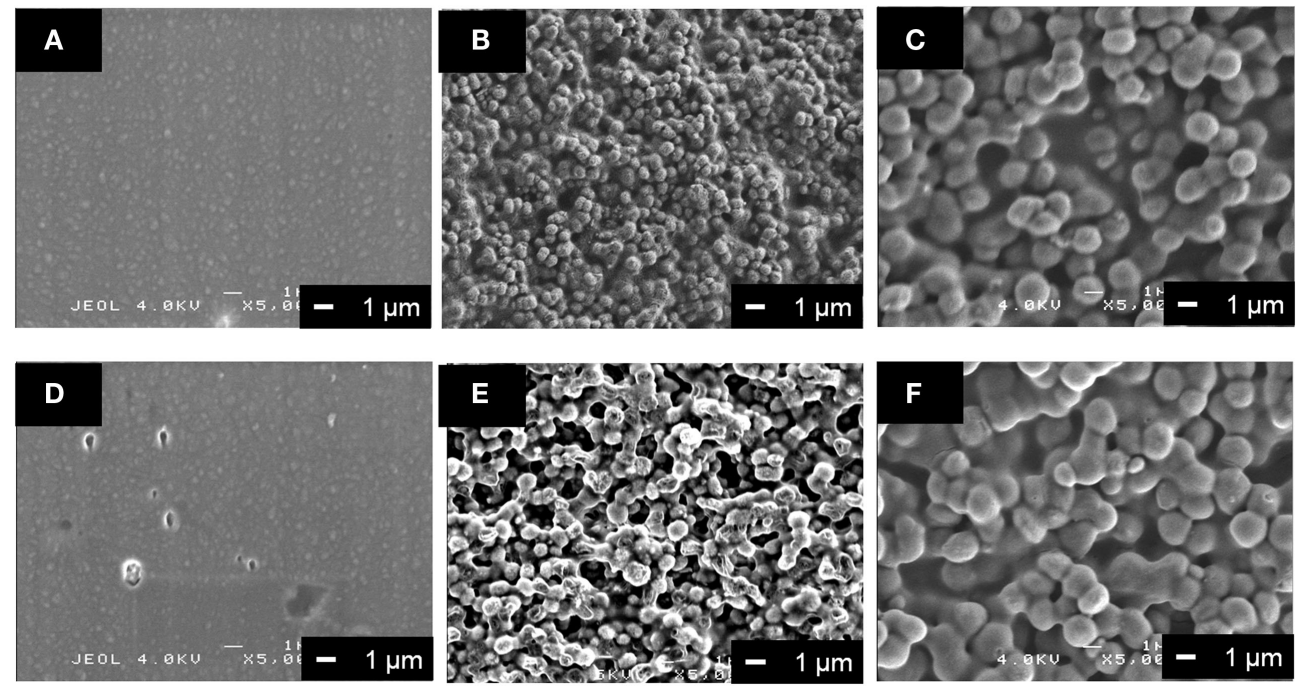

FIGURE 5 | SEM images of (A,D) PLLA coating, (B,E) PLLA/V coating, and (C,F) PLLA/SiV coating (A-C) before and (D-F) after soaking in $\alpha-M E M$ at $\mathbf{3} 7^{\circ} \mathbf{C}$ for $\mathbf{7}$ days. Reprinted with permission from Yamada et al. (2013).

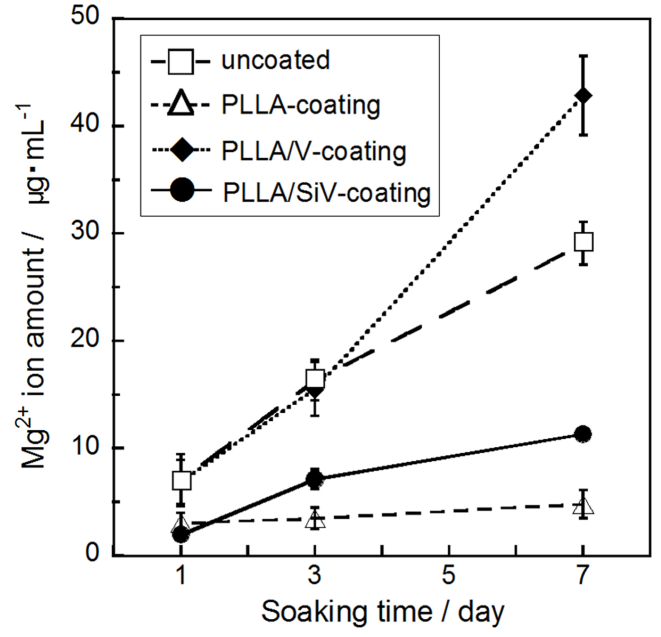

FIGURE 6 | $\mathrm{Mg}^{2+}$ ion concentrations dissolved from uncoated, PLLA coating, PLLA/V coating, and PLLA/SiV coating. Reprinted with permission from Yamada et al. (2013).

from the PLLA/SiV- and PLLA/V-coated samples may influence the cell proliferation, since the two ions have been reported to influence osteoblast functions (Diba et al., 2012).

Although there was no significant difference in the proliferation between the PLLA/SiV and PLLA/V coatings, adhering and spreading of the cells varied between the two. The morphology of the cells cultured on the two samples was observed after staining with a Giemsa's solution (Figure 7C). The cells exhibit spindlelike shape on the PLLA/SiV coating, while they did circular and a less-spread shape on the PLLA/V one. The aspect ratios of the cells varied between the two samples; the ratio of PLLA/SiV samples was higher than that of the PLLA/V ones. The proliferation is comparable between the two samples; nevertheless, the instability of the PLLA/V coatings as shown in Figure 5E might inhibit the cell spreading.

The osteogenic differentiation of the cells varied on the three types of coated samples. The rank order of the ALP activity was the $\mathrm{PLLA} / \mathrm{SiV}>\mathrm{PLLA} / \mathrm{V}>$ pure PLLA $\approx$ the uncoated $\mathrm{Mg}$ substrate after 21 days of culturing (Figure 7B). There are two possible reasons why the differentiation varied among the samples, the shape of adhesive cells, and the ions released from the samples. Cell morphologies influence gene expression (Lavenus et al., 2011). As aforementioned, the cells showed a good spreading on the PLLA/ $\mathrm{SiV}$ coating in comparison with those on the PLLA/V ones. The good spreading should be good for exhibiting their high performances. On the other hand, the ions, especially silicate ions, are known to accelerate osteogenic cell differentiation (Xynos et al., 2001). In addition, $\mathrm{MgSiV}$ is expected to possess buffering action in aqueous solution since it releases carbonate ions as well, while most of silica-based bioactive glasses, such as 45S5-type bioactive glass, increase its surrounding $\mathrm{pH}$. This might be good for cells cultured on the material surfaces. Thus, the PLLA/SiV coating is useful for improving the cytocompatibility of the metallic $\mathrm{Mg}$ because of its strong bonding with the Mg surface, the stability in an aqueous solution, and the ability of providing three kinds of ions, $\mathrm{Mg}^{2+}, \mathrm{Ca}^{2+}$, and silicate ions, which enhance osteogenic cell functions.

\section{BONE-VOID FILLERS WITH COTTON WOOL-LIKE STRUCTURE AND ION-PROVIDING ABILITY}

Bone-void filler is one of the most common biomaterials for bone reconstruction. Materials for the bone-void fillers are required to 

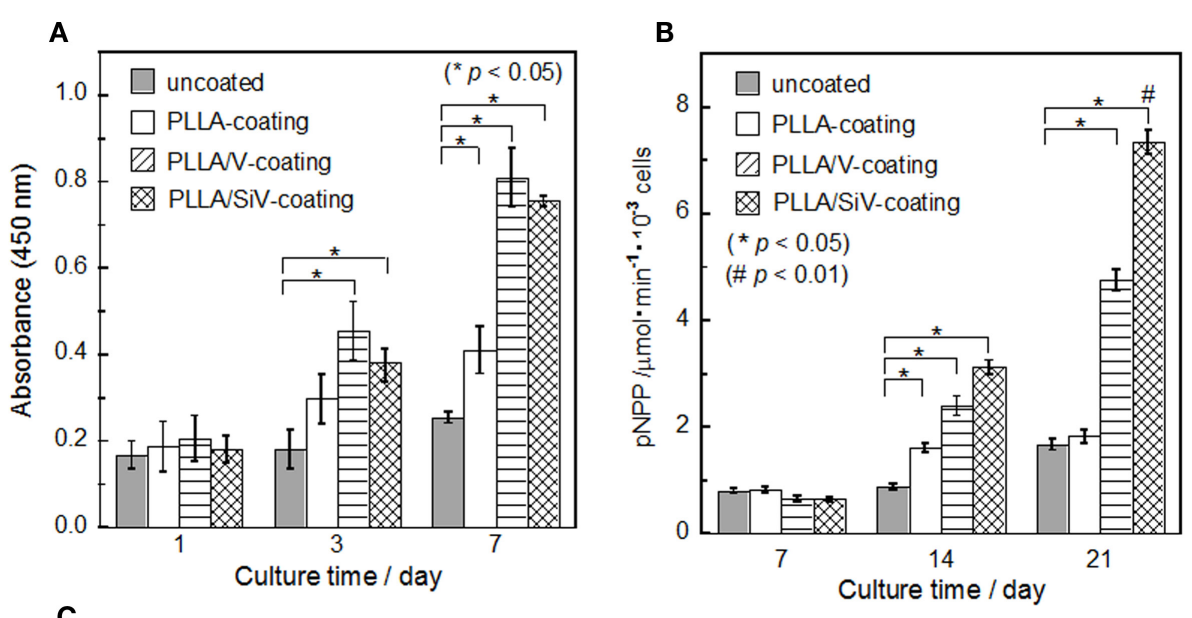

C
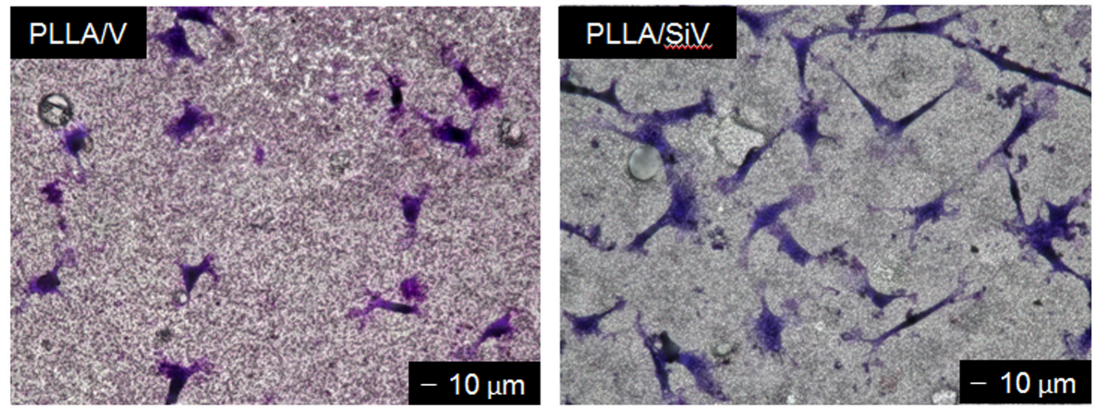

FIGURE 7 | (A) Cell number (mean \pm SEM; ${ }^{*} p<0.05$ as compared to uncoated by $t$-test), (B) ALP activity (mean \pm SEM; ${ }^{*} p<0.05$ as compared to uncoated by t-test, ${ }^{\#} p<0.05$ as compared to other three samples by Tukey's multiple comparison test), and (C) morphology of MC3T3-E1 cells cultured on samples. (C) After 3 days of culturing. Reprinted with permission from Yamada et al. (2013).

A

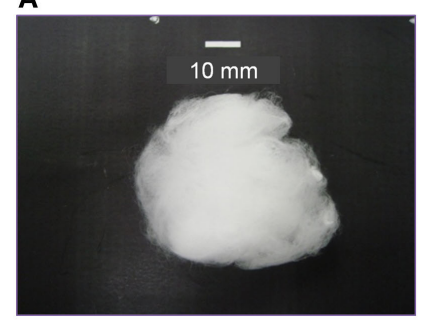

B

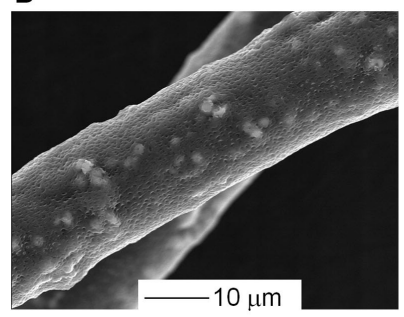

FIGURE 8 | (A) Appearance and (B) SEM images of cotton wool-like structured PLLA/SiV composites. Reprinted with permission from Obata et al. (2013).

have bioactivity and porous structure for achieving excellent cell integration and rapid bone regeneration in body. Electrospun fibremats have been widely investigated for the use in bone tissue engineering because of their flexibility and high interconnected porosity (Li et al., 2002; Sill and von Recum, 2008). A conventional electrospinning system consists of a syringe pomp, a power supply, and a metallic plate (collector). A polymer-based solution is put in a syringe set in the syringe pomp and then electrically charged with the power supply. The electrically charged solution is sprayed onto the earthed collector. Electrospun fibers tightly overlap one another on the collector, resulting in the fabrication of fibremats. However, fabricating thick fibremats, e.g., several millimeter in thickness, had been regarded to be difficult with the conventional electrospinning system, because electrospun fibers hardly sprayed onto a collector when thickness of fibremats formed reaches several hundred micrometer (Pham et al., 2006). Pore sizes of electrospun fibremats are not enough big to induce tissue ingrowth. PLLA/SiV composites having a cotton wool-like structure have been developed with two-types of our original electrospinning systems (Kasuga et al., 2012; Obata et al., 2013). The obtained samples were evaluated in their mechanical properties, ion-releasing ability, and cell compatibility.

\section{Preparation}

Two different systems for electrospinnig were used to fabricate a cotton wool-like structure. One is the system having a vessel (100 $\mathrm{mm}$ in diameter) filled with ethanol as a collector (Kasuga et al., 2012). Electrospun fibers are collected in the ethanol, which avoids adhesion between the fibers. In addition, electrical charges on electrospun fibers are expected to be neutralized instantly after entering the ethanol. The electrospun fibers contain large gaps between them, resulting in the formation of 3D structure. Another one is the system having a metallic plate collector (like a conventional system) and a fan which blows air against 
electrospun fibers (Obata et al., 2013). The air can immediately evaporate the solvent in the electrospun fibers (chloroform) in between a tip of syringe and the collector and prevent the fiber sticking to each other.

\section{Structure, Ions-Releasing Ability, and Mechanical Properties}

The PLLA composite containing 10, 20, or $30 \mathrm{wt} \%$ of SiV with a cotton wool-like structure has been successfully fabricated. The fibers are $10-20 \mu \mathrm{m}$ in diameter and have pores with $\sim 1 \mu \mathrm{m}$ in diameter on their surfaces. The SiV powders disperse inside of the fibers and some of them are observed on the fiber surfaces (Figure 8). The pores might be formed due to the evaporation of chloroform in the fibers during the electrospinning (Huang et al., 2003; Kim et al., 2005). The pores are expected to play a role in the achievement of ion releasing from the fibers in an aqueous solution. An aqueous solution must penetrate inside the fibers through the pores, and the SiV powders can be exposed to the solution even at central parts of the fibers. In fact, $\mathrm{Ca}^{2+}$ and silicate ions gradually release from the fibers and their amounts depend on the contents of $\mathrm{SiV}$ in the composite fibers. Thus, the amounts of the ions released are controllable by changing the content of SiV. When the samples are used as bonevoid fillers, they would be tightly packed into irregularly shaped bone defects. Mechanical elasticities of the prepared samples are almost the same as that of the pure PLLA sample. That is, they are able to be packed into such defects without collapse. In addition, handling of the samples during operation must be improved.

\section{REFERENCES}

Bischoff, J. L. (1968). Kinetics of calcite nucleation: magnesium ion inhibition and ionic strength catalysis. J. Geophys. Res. 73, 3315-3322. doi:10.1029/ JB073i010p03315

Böttcher, M. E., Gehlken, P.-L., and Steele, D. F. (1997). Characterization of inorganic and biogenic magnesium calcites by Fourier transform infrared spectroscopy. Solid State Ionics. 101-103, 1379-1385. doi:10.1016/S0167-2738(97)00235-X

Diba, M., Tapia, F., Boccaccini, A. R., and Strobel, L. A. (2012). Magnesiumcontaining bioactive glasses for biomedical applications. Int. J. Appl. Glass Sci. 3, 221-253. doi:10.1111/j.2041-1294.2012.00095.X

Falini, G., Fermani, S., Tosi, G., and Dinelli, E. (2009). Calcium carbonate morphology and structure in the presence of seawater ions and humic acids. Cryst. Growth Des. 9, 2065-2072. doi:10.1021/cg8002959

Falini, G., Gazzano, M., and Ripamonti, A. (1996). Magnesium calcite crystallizatin from water-alcohol mixtures. Chem. Commun. 9, 1037-1038. doi:10.1039/ cc9960001037

Fujikura, K., Lin, S., Nakamura, J., Obata, A., and Kasuga, T. (2013). Preparation of electrospun fiber mats using siloxane-containing vaterite and biodegradable polymer hybrids for bone regeneration. J. Biomed. Mater. Res. B Appl. Biomater. 101, 1350-1358. doi:10.1002/jbm.b.32952

Hoppe, A., Güldal, N. S., and Boccaccini, A. R. (2011). A review of the biological response to ionic dissolution products from bioactive glasses and glass-ceramics. Biomaterials 32, 2757-2774. doi:10.1016/j.biomaterials.2011.01.004

Huang, Z.-M., Zhang, Y.-Z., Kotaki, M., and Ramakrishna, S. (2003). A review on polymer nanofibers by electrospinning and their applications in nanocomposites. Compos. Sci. Technol. 63, 2223-2253. doi:10.1016/S0266-3538(03)00178-7

Iafisco, M., Palazzo, B., Ito, T., Otsuka, M., Senna, M., Delgado-Lopez, J. M., et al. (2012). Preparation of core-shell poly(l-lactic) acid-nanocrystalline apatite hollow microspheres for bone repairing applications. J. Mater. Sci. Mater. Med. 23, 2659-2669. doi:10.1007/s10856-012-4732-1

\section{Cell Compatibility}

The cotton wool-like structured samples are required to have the ability of cell penetration to achieve rapid bone regeneration inside of them in body. Although the pore size of the samples can be easily varied by mechanically pressing, when their porosity is set to 90 and $96 \%$, the pore sizes in the samples are enough to induce the cell penetration. Results of culture tests using MC3T3-E1 cells for the samples with 90 and 96\% in porosity demonstrated that cells successfully migrate into the cotton woollike structures and proliferate inside of them. In addition, the live cell numbers in the cotton wool-like structures were significantly higher than those on the fibremats. This implies that the cotton wool-like structure can provide a large space allowing the cells to adhere and proliferate.

\section{SUMMARY}

Since inorganic ions were found to stimulate osteogenic cells to proliferate, differentiate, and mineralize, several types of biomaterials releasing such ions have been developed. In this review, we focused on materials releasing three types of ions, $\mathrm{Ca}^{2+}, \mathrm{Mg}^{2+}$, and silicate ions, and their cytocompatibility with osteoblast-like cells. The materials possessed the controlled release of the ions in the culture media. Providing several types of the ions simultaneously was important for achieving enhanced cell functions. Especially, the materials releasing all the three types of ions exhibited higher properties than the others in the results of cell culture tests. Combinatorial effects of inorganic ions provided on cells might exist and are expected to be minutely clarified in the future.

Jarcho, M. (1981). Calcium phosphate ceramics as hard tissue prosthetics. Clin. Orthop. Relat. Res. 157, 259-278.

Kasuga, T., Obata, A., Maeda, H., Ota, Y., Yao, X., and Oribe, K. (2012). Siloxanepoly(lactic acid)-vaterite composites with 3D cotton-like structure. J. Mater. Sci. Mater. Med. 23, 2349-2357. doi:10.1007/s10856-012-4607-5

Kim, G.-T., Lee, J.-S., Shin, J.-H., Ahn, Y.-C., Hwang, Y.-J., Shin, H.-S., et al. (2005). Investigation of pore formation for polystyrene electrospun fiber: effect of relative humidity. Korean J. Chem. Eng. 22, 783-788. doi:10.1007/ BF02705799

Kitamura, M. (2001). Crystallization and transformation mechanism of calcium carbonate polymorphs and the effect of magnesium ion. J. Colloid Interface Sci. 236, 318-327. doi:10.1006/jcis.2000.7398

Kitano, Y. (1962). The behavior of various inorganic ions in the separation of calcium carbonate from a bicarbonate solution. Bull. Chem. Soc. Jpn. 35, 1973-1980. doi:10.1246/bcsj.35.1973

Lavenus, S., Berreur, M., Trichet, V., Pilet, P., Louarn, G., and Layrolle, P. (2011). Adhesion and osteogenic differentiation of human mesenchymal stem cells on titanium nanopores. Eur. Cell. Mater. 22, 84-96.

LeGeros, R. Z. (2002). Properties of osteoconductive biomaterials: calcium phosphates. Clin. Orthop. Relat. Res. 395, 81-98. doi:10.1097/00003086-200202000-00009

Li, W. J., Laurencin, C. T., Caterson, E. J., Tuan, R. S., and Ko, F. K. (2002). Electrospun nanofibrous structure: a novel scaffold for tissue engineering. J. Biomed. Mater. Res. 60, 613-621. doi:10.1002/jbm.10167

Maeno, S., Niki, Y., Matsumoto, H., Morioka, H., Yatabe, T., Funayama, A., et al. (2005). The effect of calcium ion concentration on osteoblast viability, proliferation and differentiation in monolayer and 3D culture. Biomaterials 26, 4847-4855. doi:10.1016/j.biomaterials.2005.01.006

Maier, J. A., Bernardini, D., Rayssiguier, Y., and Mazur, A. (2004). High concentrations of magnesium modulate vascular endothelial cell behaviour in vitro. Biochim. Biophys. Acta 1689, 6-12. doi:10.1016/j.bbadis.2004.02.004 
Morse, J. W., Wang, Q., and Tsio, M. Y. (1997). Influences of temperature and Mg:Ca ratio on $\mathrm{CaCO} 3$ precipitates from seawater. Geology 25, 85-87. doi:10.1 130/0091-7613(1997)025<0085:IOTAMC>2.3.CO;2

Nakamura, J., Poologasundarampillai, G., Jones, J. R., and Kasuga, T. (2013). Tracking the formation of vaterite particles containing aminopropyl-functionalized silsesquioxane and their structure for bone regenerative medicine. J. Mater. Chem. B 1, 4446-4454. doi:10.1039/c3tb20589d

Obata, A., Hotta, T., Wakita, T., Ota, Y., and Kasuga, T. (2010). Electrospun microfiber meshes of silicon-doped vaterite/poly(lactic acid) hybrid for guided bone regeneration. Acta Biomater. 6, 1248-1257. doi:10.1016/j.actbio.2009.11.013

Obata, A., Ozasa, H., Kasuga, T., and Jones, J. R. (2013). Cotton wool-like poly(lactic acid)/vaterite composite scaffolds releasing soluble silica for bone tissue engineering. J. Mater. Sci. Mater. Med. 24, 1649-1658. doi:10.1007/ s10856-013-4930-5

Obata, A., Tokuda, S., and Kasuga, T. (2009). Enhanced in vitro cell activity on silicon-doped vaterite/poly(lactic acid) composites. Acta Biomater. 5, 57-62. doi:10.1016/j.actbio.2008.08.004

Park, A., and Cima, L. G. (1996). In vitro cell response to differences in polyL-lactide crystallinity. J. Biomed. Mater. Res. 31, 117-130. doi:10.1002/ jbm.1996.820310102

Pham, Q. P., Sharma, U., and Mikos, A. G. (2006). Electrospun poly ( $\varepsilon$-caprolactone) microfiber and multilayer nanofiber/microfiber scaffolds: characterization of scaffolds and measurement of cellular infiltration. Biomacromolecules 7 , 2796-2805. doi:10.1021/bm060680j

Saboori, A., Rabiee, M., Moztarzadeh, F., Sheikhi, M., Tahriri, M., and Karimi, M. (2009). Synthesis, characterization and in vitro bioactivity of sol-gel-derived $\mathrm{SiO}_{2}-\mathrm{CaO}-\mathrm{P}_{2} \mathrm{O}_{5}-\mathrm{MgO}$ bioglass. Mater. Sci. Eng. C 29, 335-340. doi:10.1016/j. msec.2008.07.004

Sawada, K., Ogino, T., and Suzuki, T. (1990). The distribution coefficients of $\mathrm{Mg}^{2+}$ ion between $\mathrm{CaCO}_{3}$ polymorphs and solution and the effects on the formation and transformation of $\mathrm{CaCO}_{3}$ in water. J. Cryst. Growth 106, 393-399. doi:10.1016/0022-0248(90)90084-X

Schubert, D., and Dunkel, T. (2003). Spin coating from a molecular point of view: its concentration regimes, influence of molar mass and distribution. Mater. Res. Innovat. 7, 314-321. doi:10.1007/s10019-003-0270-2

Shen, Y., Liu, W., Wen, C., Pan, H., Wang, T., Darvell, B. W., et al. (2012). Bone regeneration: importance of local $\mathrm{pH}$-strontium-doped borosilicate scaffold. J. Mater. Chem. 22, 8662-8670. doi:10.1039/c2jm16141a

Sill, T. J., and von Recum, H. A. (2008). Electrospinning: applications in drug delivery and tissue engineering. Biomaterials 29, 1989-2006. doi:10.1016/j. biomaterials.2008.01.011

Staiger, M. P., Pietak, A. M., Huadmai, J., and Dias, G. (2006). Magnesium and its alloys as orthopedic biomaterials: a review. Biomaterials 27, 1728-1734. doi:10.1016/j.biomaterials.2005.10.003

Wakita, T., Obata, A., Poologasundarampillai, G., Jones, J. R., and Kasuga, T. (2010). Preparation of electrospun siloxane-poly(lactic acid)-vaterite hybrid fibrous membranes for guided bone regeneration. Compos. Sci. Technol. 70, 1889-1893. doi:10.1016/j.compscitech.2010.05.014

Wang, J., and Becker, U. (2009). Structure and carbonate orientation of vaterite (CaCO3). Am. Mineral. 94, 380-386. doi:10.2138/am.2009.2939

Winter, M., Griss, P., de Groot, K., Tagai, H., Heimke, G., von Dijk, H. J., et al. (1981). Comparative histocompatibility testing of seven calcium phosphate ceramics. Biomaterials 2, 159-IN151. doi:10.1016/0142-9612(81)90043-0

Witte, F. (2010). The history of biodegradable magnesium implants: a review. Acta Biomater. 6, 1680-1692. doi:10.1016/j.actbio.2010.02.028
Witte, F., Hort, N., Vogt, C., Cohen, S., Ulrich Kainer, K., Willumeit, R., et al. (2008). Degradable biomaterials based on magnesium corrosion. Curr. Opin. Solid State Mater. Sci. 12, 63-72. doi:10.1016/j.cossms.2009.04.001

Witte, F., Kaese, V., Haferkamp, H., Switzer, E., Meyer-Lindenberg, A., Wirth, C. J., et al. (2005). In vivo corrosion of four magnesium alloys and the associated bone response. Biomaterials 26, 3557-3563. doi:10.1016/j. biomaterials.2004.09.049

Wong, H. M., Yeung, K. W., Lam, K. O., Tam, V., Chu, P. K., Luk, K. D., et al. (2010). A biodegradable polymer-based coating to control the performance of magnesium alloy orthopaedic implants. Biomaterials 31, 2084-2096. doi:10.1016/j. biomaterials.2009.11.111

$\mathrm{Xu}$, L., and Yamamoto, A. (2012). Characteristics and cytocompatibility of biodegradable polymer film on magnesium by spin coating. Colloids Surf. B Biointerfaces 93, 67-74. doi:10.1016/j.colsurfb.2011.12.009

Xynos, I. D., Edgar, A. J., Buttery, L. D., Hench, L. L., and Polak, J. M. (2000a). Ionic products of bioactive glass dissolution increase proliferation of human osteoblasts and induce insulin-like growth factor II mRNA expression and protein synthesis. Biochem. Biophys. Res. Commun. 276, 461-465. doi:10.1006/ bbrc. 2000.3503

Xynos, I. D., Hukkanen, M. V., Batten, J. J., Buttery, L. D., Hench, L. L., and Polak, J. M. (2000b). Bioglass ${ }^{\circledR} 45 \mathrm{~S} 5$ stimulates osteoblast turnover and enhances bone formation in vitro: implications and applications for bone tissue engineering. Calcif. Tissue Int. 67, 321-329. doi:10.1007/s002230001134

Xynos, I. D., Edgar, A. J., Buttery, L. D., Hench, L. L., and Polak, J. M. (2001). Gene-expression profiling of human osteoblasts following treatment with the ionic products of Bioglass ${ }^{\circledR} 45 S 5$ dissolution. J. Biomed. Mater. Res. 55, 151-157. doi:10.1002/1097-4636(200105)55:2<151::AID-JBM1001>3.0.CO;2-D

Yamada, S., Maeda, H., Obata, A., Lohbauer, U., Yamamoto, A., and Kasuga, T. (2013). Cytocompatibility of siloxane-containing vaterite/poly(L-lactic acid) composite coatings on metallic magnesium. Materials 6, 5857. doi:10.3390/ ma6125857

Yamada, S., Ota, Y., Nakamura, J., Sakka, Y., and Kasuga, T. (2014a). Preparation of siloxane-containing vaterite doped with magnesium. J. Ceram. Soc. Jpn. 122, 1010-1015. doi:10.2109/jcersj2.122.1010

Yamada, S., Yamamoto, A., and Kasuga, T. (2014b). Poly(L-lactic acid)/vaterite composite coatings on metallic magnesium. J. Mater. Sci. Mater. Med. 25, 2639-2647. doi:10.1007/s10856-014-5302-5

Zhang, Z., Xie, Y., Xu, X., Pan, H., and Tang, R. (2012). Transformation of amorphous calcium carbonate into aragonite. J. Cryst. Growth 343, 62-67. doi:10.1016/j.jcrysgro.2012.01.025

Zreiqat, H., Howlett, C. R., Zannettino, A., Evans, P., Schulze-Tanzil, G., Knabe, C., et al. (2002). Mechanisms of magnesium-stimulated adhesion of osteoblastic cells to commonly used orthopaedic implants. J. Biomed. Mater. Res. 62, 175-184. doi:10.1002/jbm.10270

Conflict of Interest Statement: The authors declare that the research was conducted in the absence of any commercial or financial relationships that could be construed as a potential conflict of interest.

Copyright (๑) 2015 Yamada, Obata, Maeda, Ota and Kasuga. This is an open-access article distributed under the terms of the Creative Commons Attribution License (CC $B Y$ ). The use, distribution or reproduction in other forums is permitted, provided the original author(s) or licensor are credited and that the original publication in this journal is cited, in accordance with accepted academic practice. No use, distribution or reproduction is permitted which does not comply with these terms. 